\title{
Sugar Beet Agronomic Performance Evolution in NW Spain in Future Scenarios of Climate Change
}

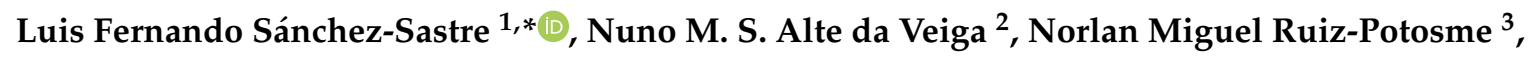 \\ Salvador Hernández-Navarro ${ }^{1}$, José Luis Marcos-Robles ${ }^{1}{ }^{1}$, Jesús Martín-Gil ${ }^{1}{ }^{10}$ and \\ Pablo Martín-Ramos ${ }^{4}$ (1) \\ 1 Department of Agricultural and Forestry Engineering, ETSIIAA, Universidad de Valladolid, 34004 Palencia, \\ Spain; salvador.hernandez@uva.es (S.H.-N.); jlmarcos@iaf.uva.es (J.L.M.-R.); mgil@iaf.uva.es (J.M.-G.) \\ 2 Departamento de Ciências da Terra, CITEUC-Centro de Investigação da Terra e do Espaço, \\ Universidade de Coimbra, 3040-004 Coimbra, Portugal; ndaveiga@ci.uc.pt \\ 3 Department of Technical Education, European University Miguel de Cervantes, 47012 Valladolid, Spain; \\ nmruiz@uemc.es \\ 4 Instituto Universitario de Investigación en Ciencias Ambientales de Aragón (IUCA), EPS, \\ Universidad de Zaragoza, 22071 Huesca, Spain; pmr@unizar.es \\ * Correspondence: luxpher@gmail.com; Tel.: +34979108300
}

Received: 23 November 2019; Accepted: 7 January 2020; Published: 9 January 2020

\begin{abstract}
Changes in environmental conditions resulting from Climate Change are expected to have a major impact on crops. In order to foresee adaptation measures and to minimize yield decline, it is necessary to estimate the effect of those changes on the evapotranspiration and on the associated irrigation needs of crops. In the study presented herein, future conditions extracted from RCP4.5 scenario of IPCC, particularized for Castilla-y-León (Spain), were used as inputs for FAO crop simulation model (AquaCrop) to estimate sugar beet agronomic performance in the medium-term (2050 and 2070). A regional analysis of future trends in terms of yield, biomass and $\mathrm{CO}_{2}$ sequestration was carried out. An annual $\mathrm{ET}_{0}$ increase of up to $200 \mathrm{~mm}$ was estimated in 2050 and 2070 scenarios, with ETc increases of up to $40 \mathrm{~mm} / \mathrm{month}$. At current irrigation levels, temperature rise would be accompanied by a $9 \%$ decrease in yield and a ca. $6 \%$ decrease in assimilated $\mathrm{CO}_{2}$ in the 2050 and 2070 scenarios. However, it is also shown that the implementation of adequate adaptation measures, in combination with a more efficient irrigation management, may result in up to $17 \%$ higher yields and in the storage of between $9 \%$ and $13 \%$ higher amounts of $\mathrm{CO}_{2}$.
\end{abstract}

Keywords: adaptation measures; AquaCrop; $\mathrm{AR} 5 ; \mathrm{CO}_{2}$; evapotranspiration; sugar beet; yield

\section{Introduction}

Spring-sown sugar beet is an industrial crop of great importance in Castilla-y-León region (Northwestern Spain), which accounts for $87 \%$ of Spanish production of spring-sown sugar beet, with over 24,000 ha [1], and which is the area of the European Union that achieves the highest yields per hectare [2]. As it is also the case for many other crops in Continentalized Mediterranean climate areas, sugar beet requires more water than that provided by rainfall, and thus irrigation is necessary to satisfy its water requirements. Besides, irrigation is the most determining factor in its production, being an indispensable practice in Spain [3]. However, the availability of water for crop irrigation is expected to decrease in the future due to increased demands from other sectors (drinking and household needs, recreation, industry and commerce, etc.) and because of changes in environmental conditions $[4,5]$. The latter are, in fact, the main source of uncertainty for the viability of sugar beet cultivation in this region in the future. 
Crop water requirements, estimated by the evapotranspiration (ET), are the sum of crop transpiration and evaporation from soil and vegetation surfaces, and they depend on local climatic conditions (temperature, humidity, wind speed, and solar radiation) [6,7]. Several studies have confirmed an increase in the reference evapotranspiration $\left(\mathrm{ET}_{0}\right)$ under Climate Change conditions in the Mediterranean area [8], and specifically in Spain [9,10]. For instance, Vicente-Serrano et al. [10] reported an average annual change increase in $\mathrm{ET}_{0}$ of $29.4 \mathrm{~mm}$ each decade from 1961 to 2011. Besides this increase in $\mathrm{ET}_{0}$, rainfall decreased $18.7 \mathrm{~mm}$ per decade in the same period [11].

The four SRES (Special Reports on Emission Scenarios) scenarios of the Intergovernmental Panel on Climate Change (IPCC) Fourth Assessment Report AR4 [12] were replaced in the IPCC Fifth Assessment Report (AR5) by four new scenarios of RCP (Representative Concentration Pathways) emission trajectories proposed by van Vuuren et al. [13]. These are defined by their total radiative forcing $\left(2.6,4.5,6.0\right.$, and $8.5 \mathrm{~W} \cdot \mathrm{m}^{-2}$ in 2100, corresponding to RCP2.6, RCP4.5, RCP6.0, and RCP8.5, respectively), and they can take into account the policies aimed at restricting Climate Change. Each RCP is based on an internally consistent set of socioeconomic assumptions, and a stringent mitigation scenario (RCP2.6), two medium stabilization forcing scenarios (RCP4.5 and RCP6.0), and one scenario with a very high level of GHG emissions (RCP8.5) are considered.

According to AR5 data [14], the global mean surface temperature change for mid-21st century relative to $1986-2005$ will range from 0.4 to $2.6^{\circ} \mathrm{C}$, depending on $\mathrm{RCPs}$, and from 0.3 to $4.8^{\circ} \mathrm{C}$ at the end of the century. Regarding rainfall, changes will not be uniform at different latitudes, but hydrological resources for the crops are generally expected to decrease in a significant manner [15].

In this context, crop growth/yield simulation models may be regarded as essential tools to evaluate the effects of environmental changes on crop physiology and to predict crops performance in climate conditions different to current ones [16].

Numerous studies that use simulation models to assess the impact of climate change on future crop yields have been published in the last years [17]. Among these models, AquaCrop-developed by the Food and Agriculture Organization of the United Nations (FAO)—stands out due to its balance between accuracy, simplicity and strength, and because it is particularly well suited to conditions in which water is a key limiting factor [18,19]. Its application has been recommended for multiple purposes, such as harvest evaluation in different geographic locations and future climate scenarios, irrigation management, available water optimization, and water policies decision-support tools. Moreover, according to the United Nations Framework Convention on Climate Change (UNFCCC) [20], this model would be particularly useful to study the response of different crops under high $\mathrm{CO}_{2}$ concentrations and global warming conditions.

AquaCrop model has been applied to the prediction of climate change impacts on crop yields in different countries, and to decision making on cropping patterns and on irrigation strategies [21]. In relation to sugar beet, the model has been successfully applied to Pakistan [22,23], to northern and eastern Europe [24] and to Spain (for calibration purposes) [25].

Given that Climate Change is heterogeneous, changes at the regional scale need to be better understood [26]. As noted above, the study of trends and spatial distribution of $\mathrm{ET}_{0}$ is essential to assess future water requirements of crops, irrigation policies, and yields at regional scale [27]. The use of finer-resolution spatial data is likely to lead to a better understanding of the impacts of climate change on crop yield as well as predicting shifts in crop-specific production zones as a result of changing weather patterns [28]. Hence, in the work presented herein, ET projections and the water-driven simulation crop growth model AquaCrop have been applied to the estimation of sugar beet agronomic performance in 2050 (average for 2041-2060) and 2070 (average for 2061-2080) in Castilla-y-León. Adaptation measures, including shifting sowing dates, extending the cultivation period (since lengthening of the growing season has a strong positive effect on sugar beet yield) or moving crop fields to cooler regions $[29,30]$ are put forward. In addition, the net $\mathrm{CO}_{2}$ uptake of this crop has been studied. 


\section{Materials and Methods}

\subsection{Area of Study}

The area of study included most of the sugar beet cultivation areas in Castilla-y-León (Figure 1). This region, located in the Spanish spring-sown sugar beet area, is known as the northern sugar beet cultivation zone. The nine provinces of Castilla-y-León are represented to certain extent, although Valladolid would be the only province whose surface is completely inside the area of study.

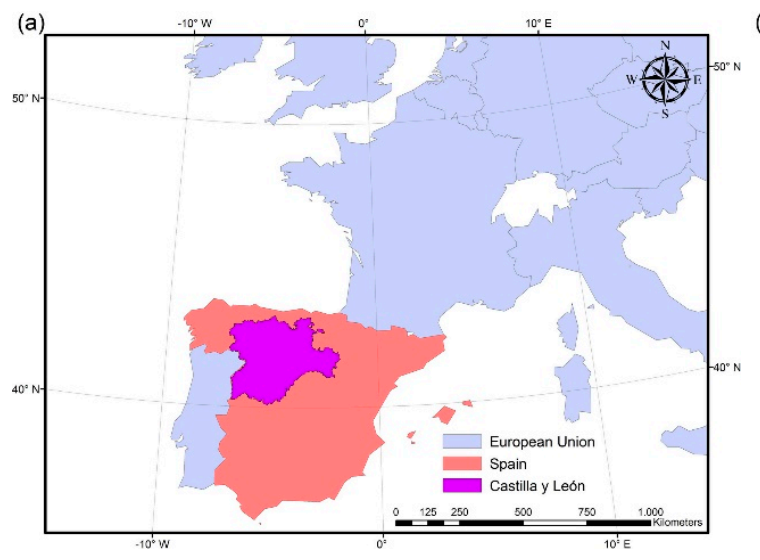

(b)

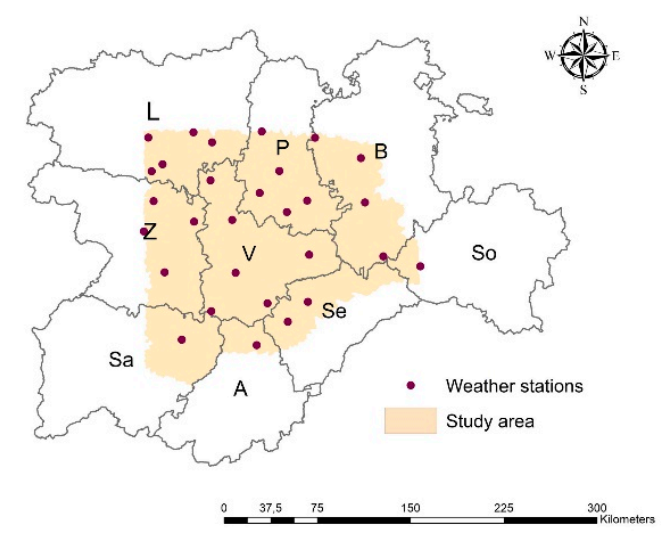

Figure 1. (a) Location of the region under study (Castilla-y-León) in Europe. (b) Location of the weather stations (red dots) and the sugar beet cultivation area covered in this study (in yellow). Administrative divisions of the region (provinces) are also shown. Province codes are as follows: L (León), P (Palencia), B (Burgos), Z (Zamora), V (Valladolid), So (Soria), Sa (Salamanca), A (Ávila), and Se (Segovia).

\subsection{Baseline Scenario Climatic Data}

As indicated in the flowchart shown in Figure S1, daily climatic data from 2001 to 2014 was collected from 29 weather stations that belong to the SIAR (Agroclimatic Information System for Irrigation) network of the MAPA (Spanish Ministry of Agriculture, Fisheries and Food). This climatic data was used to calculate a representative meteorological year for each season, in order to build the baseline scenario for the study. This time series was chosen over other longer (but less local) data series because field data can improve the regional projections of crop models [31]. Mann-Kendall tau test was conducted to detect trends in the dataset.

\subsection{Projected Climatic Data for 2050 and 2070 Scenarios}

Climate data projected for 2050 and 2070 in the locations of the SIAR stations were obtained through the WorldClim global climate layers [32] (http://www.worldclim.org). In this project, different global climate models output data from CMIP5 (IPCC Coupled Model Intercomparison Project Phase 5) were downscaled and calibrated (bias corrected) using WorldClim 1.4 as a reference baseline "current" climate [33]. More information on CMIP5 coordinated multi-model dataset, which ensembles 40 GCMs (Global Climate Model) from 20 research groups, may be found in Taylor et al. [34]. Future climate data generated with those GCMs usually has a spatial resolution of hundreds of kilometers, which is problematic for regional studies that consider variation at much higher spatial resolution. Hence, high-resolution information from low-resolution variables needs to be inferred through a downscaling process, which can be conducted in different ways [35]. In particular, WorldClim project uses a methodology that assumes that change in climate is relatively stable over space (high spatial autocorrelation).

The layers selected in this study (monthly average minimum temperature, monthly average maximum temperature and monthly total precipitation) were projections of the Earth system model MPI-ESM-LR, developed by the Max Planck Institute for Meteorology (MPI-M) for RCP4.5, and had 
a 30-s (of a longitude/latitude degree) spatial resolution (about $900 \mathrm{~m}$ at the equator), and 1 month temporal resolution. The MPI-ESM consists of coupled general circulation models for the atmosphere and the ocean, as well as subsystem models for land and vegetation, and for the marine biogeochemistry. Thus, the carbon cycle has been added to the model system [36].

RCP4.5 scenario, which represents stabilization without overshoot pathway to $4.5 \mathrm{~W} \cdot \mathrm{m}^{-2}$ at stabilization after 2100 [37,38], was chosen because it is not as optimist regarding GHG reduction as RCP2.6, but it does consider a reduction in greenhouse gases starting before 2050. In this model, global mean surface temperature change is estimated at $1.4^{\circ} \mathrm{C}$ in $2046-2065$, and at $1.8^{\circ} \mathrm{C}$ in $2081-2100$.

\subsection{Calculated Reference Evapotranspiration and Crop Evapotranspiration}

Penman-Monteith simplified equation [39], adopted by the FAO, was used for the calculation of monthly and annual $\mathrm{ET}_{0}$ values, both in 2050 (average for 2041-2060) and 2070 (average for 2061-2080), using temperature and precipitation data from previous section. Wind, humidity and radiation parameters were assumed stationary. The choice of this method would be supported by the fact that many studies have successfully applied it to different climates and time scales [40]. Moreover, in Spain it has been used, for example, by Espadafor et al. [9] and by Vicente-Serrano et al. [10] to examine historical trends of $\mathrm{ET}_{0}$.

To validate this method, calculated values were compared with real values coming from the stations, and regression lines were obtained, obtaining a coefficient of determination $R^{2}$ of 0.998 (thus confirming that the method of calculation was perfectly acceptable).

Monthly crop evapotranspiration (ETc) was calculated as the product of monthly $\mathrm{ET}_{0}$ and Kc crop-specific coefficients. Monthly values for sugar beet $K_{C}$ in the area of study were obtained from AIMCRA (Spanish Research Association for Sugar Beet Crop Improvement) [41].

\subsection{AquaCrop}

A detailed description of the model can be found in [42] and [18]. Minimum and maximum temperatures, $\mathrm{ET}_{0}$, rainfall and $\mathrm{CO}_{2}$ concentrations (from Mauna Loa Observatory (Hawaii) records and estimated values for the future, discussed in Section 2.3) were supplied as climate inputs. An appropriate irrigation schedule for crops in this region, based on AIMCRA recommendations [41], with a total dose of $553 \mathrm{~mm}$ during the whole cycle, was chosen. This irrigation dose was considered as fixed for predictions in the future scenarios.

\subsubsection{Crop Model Calibration}

By default AquaCrop offers files for the simulation of different crops, and in the case of sugar beet, the model is automatically calibrated and validated to Foggia (Italy) in 2000. Stricevic et al. [43] calibrated the model for the specific conditions of northern Serbia, concluding that this calibration only implied small changes of a few of the default model coefficients, illustrating the resilience of the model. Garcia-Vila et al. [25] recently calibrated and validated the model for different irrigation water allocations in the two main producing areas in Spain. Consequently, in this study the crop parameters for sugar beet were adjusted taking into consideration aforementioned works to obtain typical yields in the area of study (of over $100 \mathrm{t} / \mathrm{ha}$ ).

In general, it is more suitable to study the different crop stages through the growing-degree days (GDD), to better reflect the plant physiology [17]. In this study, GDD was used for the baseline scenario, and both GDD and days were used for future projections of the crop growth cycle (GDD for comparisons with the baseline scenario and days for the extended cultivation period calculations). The necessary GDD to achieve each growth stage (Table 1) were chosen on the basis of field data collected in different locations in the area of study [44] and on data available in the literature. Details on sowing and harvesting dates have been reported in a previous paper [44]. 
Table 1. GDD (Growth degree-day after sowing) for each sugar beet growth stage. Date of crop emergence was defined as the date on which $50 \%$ of seedlings had emerged.

\begin{tabular}{ccc}
\hline Stage & GDD & Source \\
\hline Emergence & 190 & {$[44,45]$} \\
$85 \%$ canopy & 900 & {$[46]$} \\
$100 \%$ canopy & 1200 & {$[47]$} \\
Maturity & $>3000$ & {$[44]$} \\
\hline
\end{tabular}

As in the calibration proposed by Garcia-Vila et al. [25], it was also decided to slightly increment the water productivity (WP) parameter. This modification would be supported by the conclusions of previous research works that suggest that, although sugar beet is a C3 species, it is very efficient in water use, with a behavior closer to that of $\mathrm{C} 4$ crops [48]. Planting density in the model was increased to 125,000 plants/ha, which was the density used in real cultivation conditions [41,44]. The harvest index (HI) was kept at 70\%, in agreement with Martínez Quesada [49] and with field data. As in the study by Stricevic et al. [43], soil fertility was not addressed, given that nutrient requirements were fully satisfied following AIMCRA recommendations [41]. Soil types were not specified either.

Validation was conducted by calculating the error between real production data, available from experiments conducted in 2011 and 2012 growing seasons, and that calculated with AquaCrop. For this, as in other works [50], the root mean square error (RMSE) and the normalized root mean square error (RMSEn) were calculated. The global Root Mean Square Error (RMSE) was determined as:

$$
R M S E=\sqrt{\frac{1}{n} \sum_{i=1}^{n}(A i-S i)^{2}},
$$

where $A i=$ experimental yield, $S i=$ simulated yield and $n=$ number of observations. Units are $\mathrm{t} / \mathrm{ha}$ of dry matter yield.

The normalized root mean square error was calculated as:

$$
R M S E n=100 \frac{R M S E}{\bar{A}},
$$

where $\bar{A}=$ mean observed data. Values of RMSEn smaller than $10 \%$ are considered as excellent, between 10 and $20 \%$ as good, between $20 \%$ and $30 \%$ as fair and, if larger than $30 \%$, as poor [51].

\subsubsection{Carbon Sequestration}

Data about carbon content in the different parts of the sugar beet was obtained from experimental data [44], with average values of $43.5 \%$ in roots and $37.5 \%$ in leaves. $\mathrm{Net}^{\mathrm{CO}_{2}}$ uptake (i.e., carbon storage) was obtained by multiplying dry matter, $\mathrm{C}$ content and the $\mathrm{C}$ to $\mathrm{CO}_{2}$ conversion factor $(44 / 12$, i.e., the ratio between the molar mass of $\mathrm{CO}_{2}$ and the molar mass of $\mathrm{C}$ ).

\subsubsection{Cartography and Spatial Interpolation}

ArcGIS v.10 software (Esri, Redlands, CA, USA) was used to extract monthly average minimum and maximum temperatures and monthly total precipitation data (used as inputs to the crop model) from WorldClim layers for the coordinates of every weather station. It was also used to generate annual reference evapotranspiration, monthly crop evapotranspiration, annual yield, annual biomass and annual $\mathrm{CO}_{2}$ sequestration maps. These are shown in the results section below. As for spatial interpolation, ordinary kriging method in Geostatistical Analyst toolbox was used. A spherical isotropic semivariogram [52] was chosen on the basis of RMSE criterion. IDW (Inverse Distance Weighting) was avoided in order to minimize points isolated by bull's-eye effect, while Spline was not chosen either, 
since it would be more appropriate for smaller scales [53]. The spatial analyst toolbox from ArcGIS was used to implement this interpolation.

Interpolation validation was conducted by "leave one out" cross-validation, which consists in using one of the stations as the validation dataset, and using the rest of stations as the training set to calculate the error of the resulting model in that validation station; and then repeating this process for each and every station in the dataset.

\section{Results}

\subsection{Evapotranspirationn Baseline}

Monthly average temperature, precipitation and $\mathrm{ET}_{0}$ values from the 29 weather stations, with daily data from 2001 to 2014, are shown in Figure 2a.
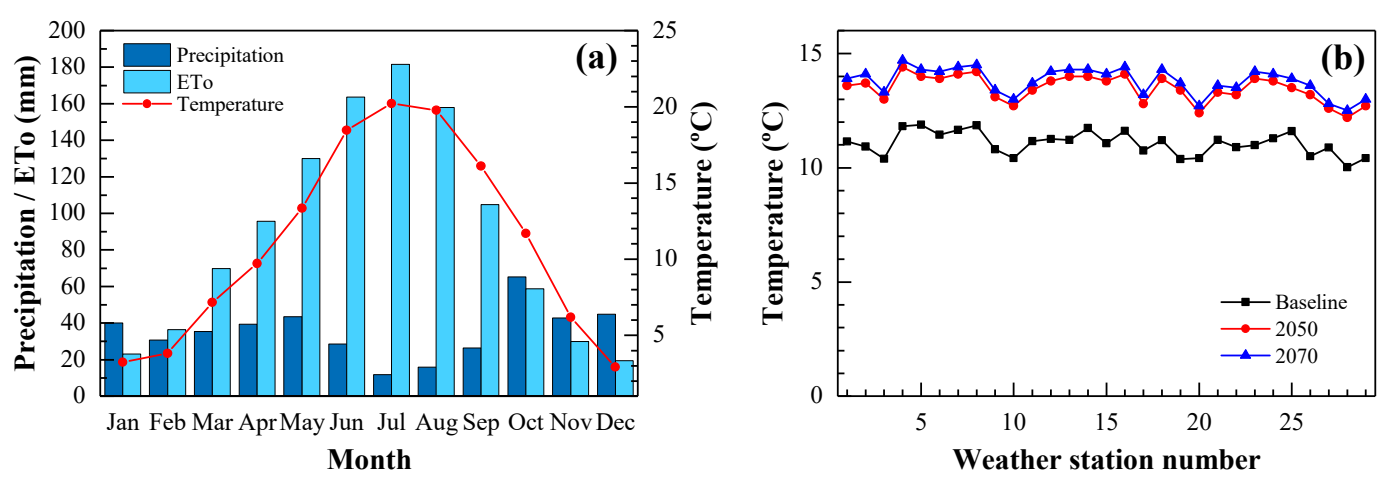

Figure 2. (a) Average monthly precipitation, $\mathrm{ET}_{0}$ and temperatures, from daily data collected from the 29 weather stations, from 2001 to 2014 (baseline scenario). (b) Annual mean temperature at the 29 weather stations. Baseline data (in black) corresponds to mean observed values from 2001 to 2014. Annual mean temperatures in 2050 (in red) and in 2070 (in blue) for the location of each station, obtained from WorldClim, are also shown.

It may be observed that the highest $\mathrm{ET}_{0}$ values were found between June and August, while the lowest ones corresponded to the November to March period, as expected in a continental Mediterranean climate.

Despite the fact that the general trend in Spain in the last decades has been towards an increase in $\mathrm{ET}_{0}[10]$, it is worth noting that Mann-Kendall trend test did not identify any clear trend in $\mathrm{ET}_{0}$ data for the years considered herein. This would be beneficial when it comes to the creation of a "representative year" model.

\subsection{WorldClim Data}

Annual average temperatures for each station in the area of the study are shown in Figure $2 b$. Data for current situation (baseline scenario) are the average values obtained from 2001 to 2014 for each station. Data from 2050 to 2070 are the values obtained from the climate layers of WorldClim.

The average temperature increase of the whole set of stations was 2.4 and $2.7^{\circ} \mathrm{C}$ for 2050 and 2070, respectively. It should be noted that these values would be higher than the global averages for the RCP4.5 scenario. Ribalaygua et al. [54], working with SRES scenarios, reported increases in maximum and minimum temperature averages ranging from 1.5 to $2.5^{\circ} \mathrm{C}$ (depending on the scenario), relative to the 1971-2000 period, for mid-21st century in Aragón (north-eastern Spanish region). In that study, regarding rainfall, authors explained that there was not a clear trend, but rather higher uncertainties. However, all the scenarios suggest a moderate decrease in rainfall for the mid-century $(2 \%-4 \%)$. In this work, the percentage of change of annual precipitations for 2050 and 2070 in the area of study (not shown) was minimum compared to the current scenario, so it should not influence the results in a significant manner. 


\subsection{Crop Model Validation}

The minor adjustments made to the calibration discussed in Section 2.5.1 showed an adequate performance when applied to the area of study, in agreement with Heng et al. [55]. In comparison with experimental data from 2011 and 2012 growing seasons, errors remained below $10 \%$ in all cases, except for one plot in 2012 (14.72\%) (Table 2). The yield RMSE value, of $2 \mathrm{t} / \mathrm{ha}$, and the yield RMSEn, below $10 \%$ (rated as 'excellent', according to [51]), imply that the model would be adequate with a view to analyzing spatial trends for the crop in future scenarios of Climate Change.

Table 2. Comparison between observed and simulated yields.

\begin{tabular}{|c|c|c|c|}
\hline Year & Site & Experimental Yield (Dry Biomass: $t \cdot h^{-1}$ ) & Simulated Yield (Dry Biomass: $\mathrm{t} \cdot \mathrm{ha}^{-1}$ ) \\
\hline 2011 & 1 & 18.50 & 20.10 \\
\hline 2011 & 2 & 24.19 & 24.86 \\
\hline 2012 & 1 & 19.28 & 22.12 \\
\hline 2012 & 2 & 24.88 & 26.79 \\
\hline \multirow[t]{2}{*}{2012} & 3 & 23.94 & 22.58 \\
\hline & & & 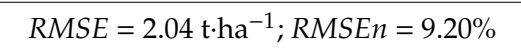 \\
\hline
\end{tabular}

\subsection{Interpolation Validation}

A "leave one out" cross-validation of $\mathrm{ET}_{0}$ values was used to assess the behavior of the spatial kriging interpolation applied to the variables under study. With a RSME of $69.5 \mathrm{~mm}$ (5.2\% mean error) between observed and interpolated values, this interpolation method may be regarded as a consistent tool for the creation of maps that are representative of the spatial distribution of the studied variables (Table S1).

\section{5. $E T_{0}$ and $E T c$}

In the baseline scenario, the central and southern zones of the area of study showed higher $\mathrm{ET}_{0}$ values, decreasing as one moves towards the periphery, especially towards the north and northeast (Burgos province). In future scenarios, a clear annual $\mathrm{ET}_{0}$ increase was calculated for all the area under study both in 2050 and in 2070 (Figure 3), more marked for the latter, with differences vs. the baseline scenario of up to $200 \mathrm{~mm}$ (Figure 4). This increase would be a direct consequence of the temperature rise, given that temperature was the only parameter modified in FAO-56 PM equation.
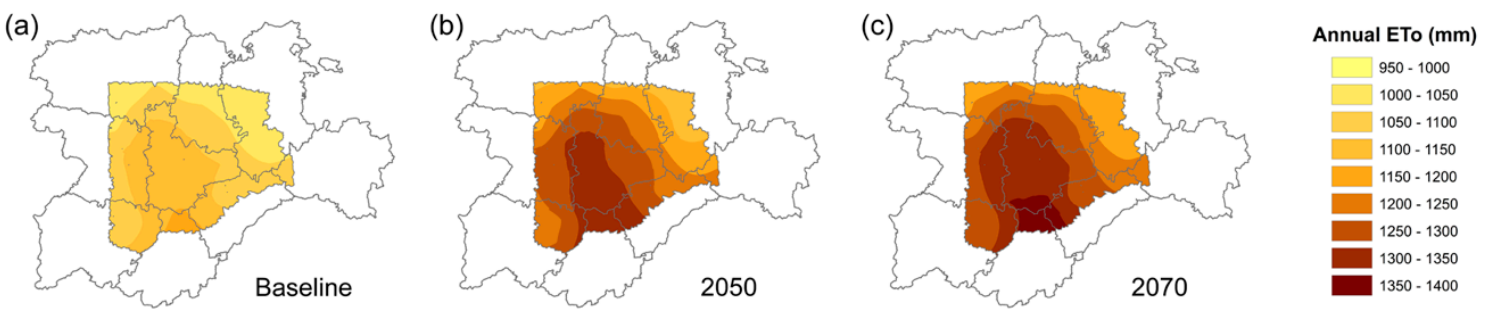

Figure 3. Spatial distribution of annual evapotranspiration $\left(\mathrm{ET}_{0}\right)$ in the area of study for the (a) baseline, (b) 2050, and (c) 2070 scenarios. 
(a)

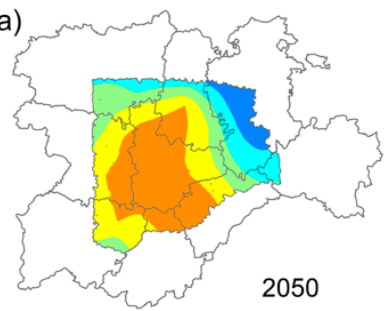

(b)

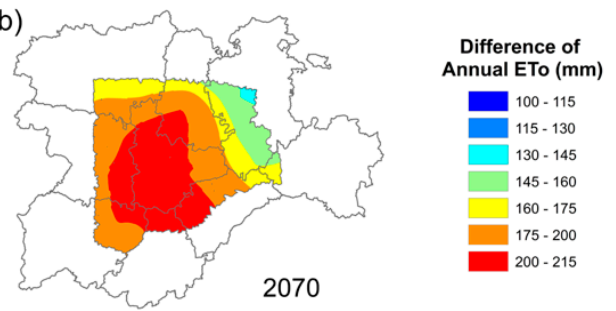

Figure 4. Spatial distribution of differences in annual $\mathrm{ET}_{0}(\mathrm{~mm})$ in the area of the study, for the (a) 2050 and (b) 2070 scenarios, compared to the baseline scenario.

Within the area of study, the areas that would be most affected by the increase in annual $\mathrm{ET}_{0}$ would be the province of Valladolid, the south of Palencia, the north of Salamanca and Ávila, the northeast of Segovia, and the east of Zamora. That is, the annual $\mathrm{ET}_{0}$ increase in future scenarios would make the spatial distribution differences that already exist in the baseline scenario more dramatic. The increase would be more marked in the central zone, with a clear southwards direction (and slightly to the west) so that areas with lower annual $\mathrm{ET}_{0}$ would move towards the north and northeast over time.

This same trend was also reflected in the monthly differences in ETc values with respect to the baseline scenario, depicted in Figure 5. Between March and May, monthly ETc increases ranging from 1.5 to $20 \mathrm{~mm} / \mathrm{month}$ are foreseen in the future scenarios. July would be the month in which the monthly ETc increase would be maximum, of up to $40 \mathrm{~mm} / \mathrm{month}$.

(a)
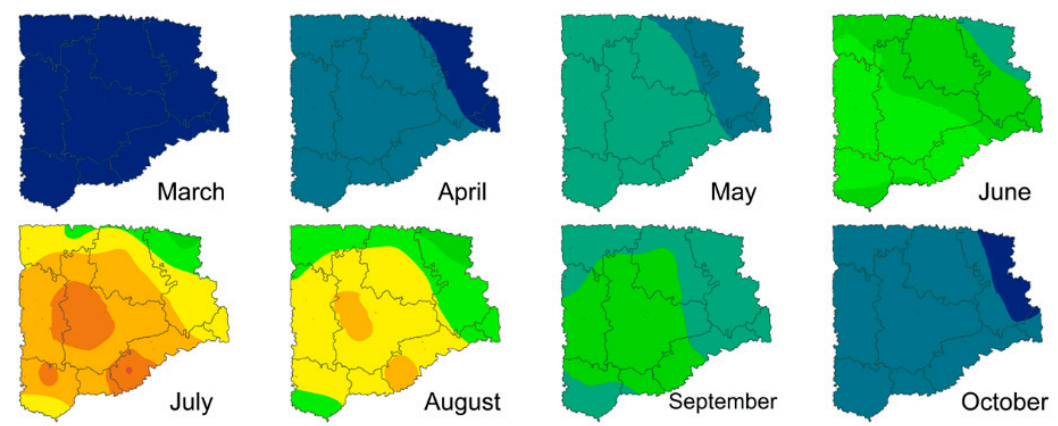

Monthly ETc change $(\mathrm{mm})$

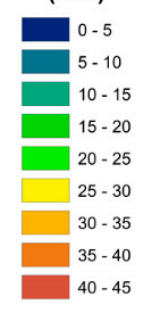

(b)
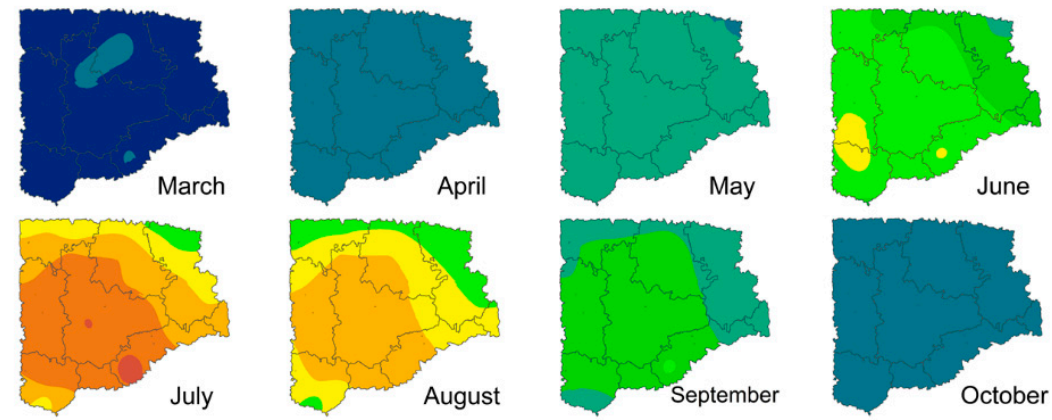

Figure 5. Spatial distribution of monthly crop evapotranspiration (ETc) changes in the area of study for (a) 2050 and (b) 2070 scenarios, compared to the baseline scenario.

\subsection{Yield}

Assuming that irrigation doses are not increased, yield would be affected by changes in $\mathrm{ET}_{0}$ (Figure 6a). Taking into consideration the pattern for annual $\mathrm{ET}_{0}$ evolution described above, yield would decrease by ca. $9 \%$ in both 2050 and 2070 in the central zone of the area of study. An in-depth analysis of modelled effects of sugar beet responses to different irrigation doses may be found in [25]. 
(a)

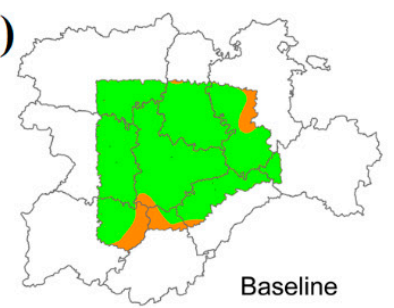

(b)

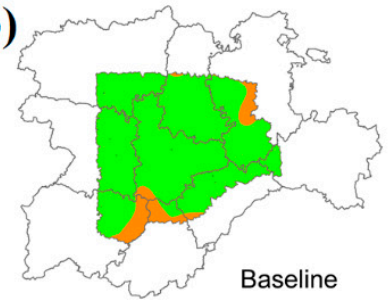

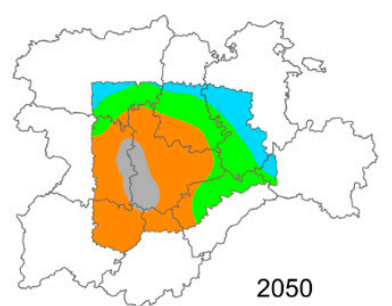

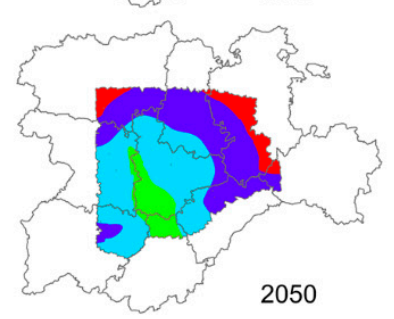

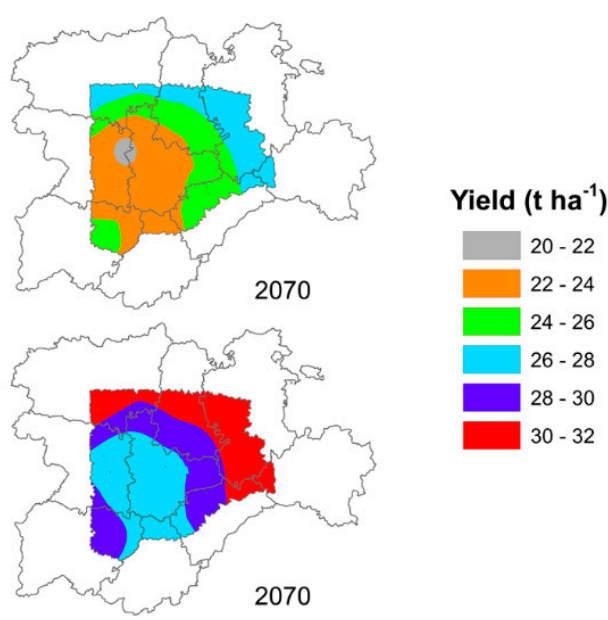

Figure 6. Yield spatial distribution in the area of study in the 2050 and 2070 scenarios vs. the baseline scenario with (a) current cultivation period, (b) extended cultivation period.

It is worth noting that the decrease in yield would be slightly larger in 2050 than in 2070 . This unexpected result may be tentatively ascribed to a higher photosynthetic activity in 2070 resulting from higher $\mathrm{CO}_{2}$ concentrations. That is, the negative effect of higher temperatures would be partly compensated by larger photosynthetic rates due to the expected $\mathrm{CO}_{2}$ increase [56]. This would be consistent with studies that have carried out FACE (Free Air Carbon Enrichment) experiments to simulate future scenarios with larger $\mathrm{CO}_{2}$ concentrations, such as those by Manderscheid et al. [57], finding a yield increase between $7 \%$ and $16 \%$ for the $\mathrm{CO}_{2}$ concentration levels foreseen for mid-21st century in the A1B IPCC scenario (SARS scenario). The projections of Vanuytrecht et al. [58] for sugar beet in Belgium showed that although higher temperatures and a shorter growth period alone would reduce potential yield, sugar beet would substantially benefit from the $\mathrm{CO}_{2}$ fertilization effect (with a mid-century yield increase between $6 \%$ and $13 \%$ ).

On the other hand, an increase in yield would be expected in 2050 in northwestern León and northeastern Burgos, an area that would expand to include also the north of Palencia in 2070, reaching a 10\% yield increase. This can be explained because, in these colder zones in the baseline scenario, the plants would actually benefit from the higher temperatures. Therefore, as it has been reported for other crops, future global warming may be beneficial in some regions [50,59], but may reduce productivity in zones where optimal temperatures already exist [60]. Moreover, a shorter crop cycle may result in a reduction of attainable yield $[30,61]$ or in a yield increment $[31,59]$ depending on the crop, the region and the chosen adaptation strategies, such as matching crops to soils [29]. Other strategies such as shifting the sowing date, changing the required cultivar growth duration, the development of heat tolerant plants may have to be adopted depending on the location and crop, as noted by Khordadi et al. [30].

Concerning the study presented herein, an important point that should be taken into consideration is that the yield simulations generated by the model in 2050 and 2070 involve changes in the crop cultivation period. While in the baseline scenario sugar beet cultivation goes from March until November, in future simulations the crop season would start earlier, and would finish by October or by the end of September, depending on the area. This responds to the fact that crops, with increasing temperatures, take less time to reach the necessary GDD in each growth stage. Although the temperature rise can increase the developmental rate of the crop, resulting in an earlier harvest, such "heat stress" may have negative effects on crop production [16].

However, the future increase in temperatures could also allow a lengthening of the cultivation period, allowing for earlier sowing. The temperature rise would allow an earlier development of the photosynthetic organ (the leaves), making the most of solar radiation: Due to the slow leaf development in spring, sugar beet crop achieves its highest canopy when the maximum solar radiation of the year 
has already passed [62,63]. By getting the largest field coverage in the least amount of time, and keeping this coverage for as long as possible, the plant can thus optimize solar radiation interception [64]. In this way, the softer winter temperatures could lead to higher productivity in that part of the year, somehow balancing the losses from the other seasons [56].

According to the simulations, as long as the water requirements of the plant were met with the same water allocation - which involves higher irrigation efficiencies and/or the development of new irrigation strategies [65] - if the cultivation period was extended, bigger yields could be achieved. In this sense, data about the positive influence of cycle extension on yield, based on field studies conducted in the area of study [66], suggests that yield increases of up to $20 \%$ could be attained. This would be in agreement with Hoffmann et al. [67] and Hull et al. [68], who claimed that lengthening of the growing season would have a strong positive effect on sugar beet yield. In Figure $6 b$, the simulations have been extended until November, generally obtaining larger yields, both in 2050 and 2070 (with an increase of up to 17\%). These increases would be more noticeable in the north and eastern zones than in the center and in the south. In 2070, because of higher $\mathrm{CO}_{2}$ concentrations, the increase would be more marked, especially in the northern zone (Palencia and León) and in the east (Burgos).

\subsection{Biomass and $\mathrm{CO}_{2}$}

Besides offering data on yield, AquaCrop also provides results about the total biomass achieved by the crop (Figure 7a), thus allowing to estimate $\mathrm{CO}_{2}$ sequestration (Figure 7c). As it occurred with crop yield, a decrease in the average biomass production and in $\mathrm{CO}_{2}$ assimilation of around $7 \%$ in 2050 may be expected when the entire area of study is considered. Such decrease would be slightly mitigated in 2070 ( $5 \%$ decrease) for the same reason discussed above (related to the increase in $\mathrm{CO}_{2}$ levels). In absolute terms, the assimilated $\mathrm{CO}_{2}$ would decrease from $49 \mathrm{t} / \mathrm{ha}$ in the baseline scenario to ca. 46 and ca. $47 \mathrm{t} / \mathrm{ha}$ in the 2050 and 2070 scenarios, respectively.

As in the case of yield, if the cultivation period was expanded, larger average quantities of biomass (Figure $7 \mathrm{~b}$ ) and captured $\mathrm{CO}_{2}$ (Figure $7 \mathrm{~d}$ ) would be obtained throughout the area of study, with $8 \%$ and $12 \%$ increases in 2050 and 2070, respectively. In this case, captured $\mathrm{CO}_{2}$, would evolve from 49 $\mathrm{t} /$ ha in the baseline scenario to 53 and $55 \mathrm{t} / \mathrm{ha}$ (on average) in 2050 and 2070, respectively (9 and 13\% increase, approximately).

To sum up, for the studied variables (annual $\mathrm{ET}_{0}$, monthly ETc, yield, biomass and $\mathrm{CO}_{2}$ assimilation), the trends predicted in this work would match in a regional scale what other studies have observed: A northward movement of crop suitability zones, as well as increased crop productivity in Northern Europe [69]. Furthermore, the simulations suggest that there is a greater potential for adaptation in northern, cooler zones, in which the reduction in yields can be compensated by shifting the crop growing season to cooler months [30], by advancing sowing, and by taking advantage of an extended growing period through the use of suitable varieties [70].

Although a regional approach is necessary to assess the effects of Climate Change on future yields and changes in crop suitability, it must be kept in mind that there are many uncertainties associated with this kind of yield simulations, including uncertainties in the GCM models and projections of future climate [70], crop model uncertainties [61,71], assumptions, and observation errors [72]. To these, other likely factors such as an increase in extreme rainfall events and droughts may be added, which should also be taken into consideration in future studies $[59,69]$. 
(a)

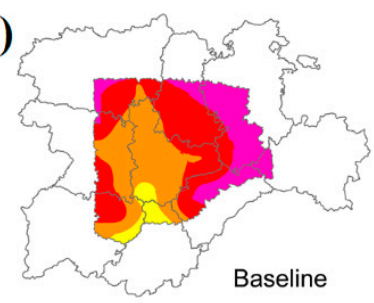

(b)

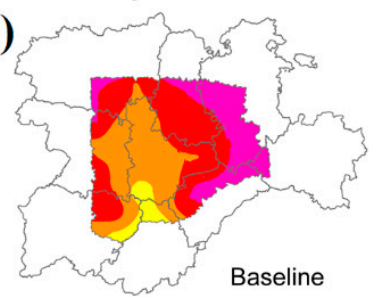

(c)

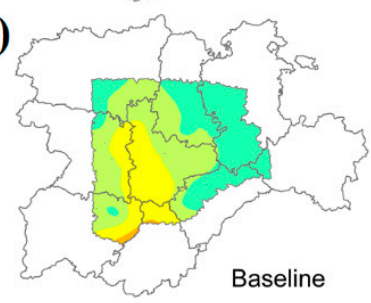

(d)

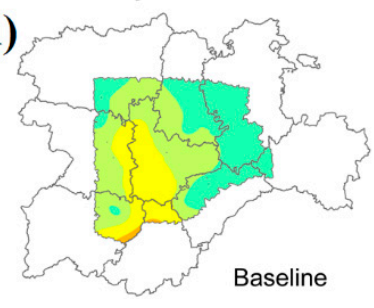

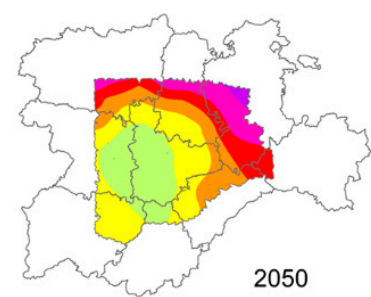

2050

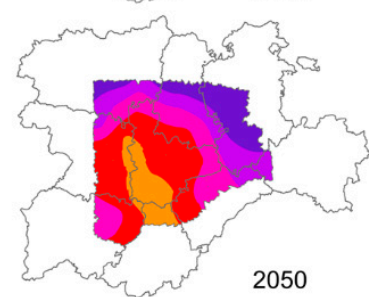

2050

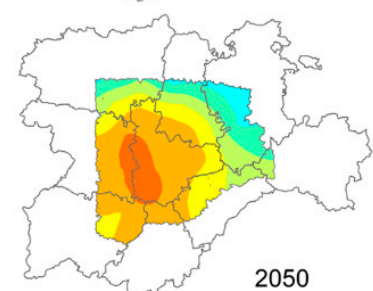

2050

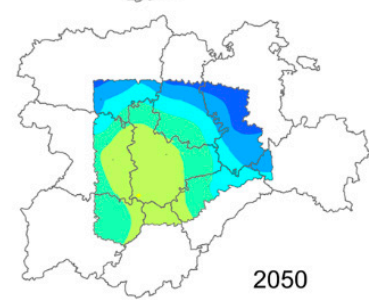

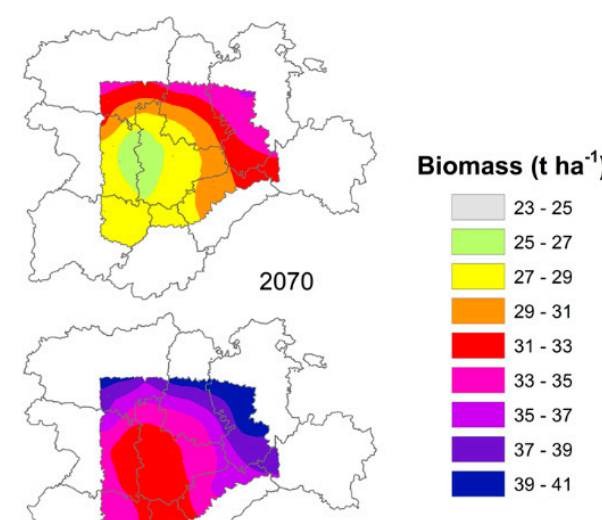

2070

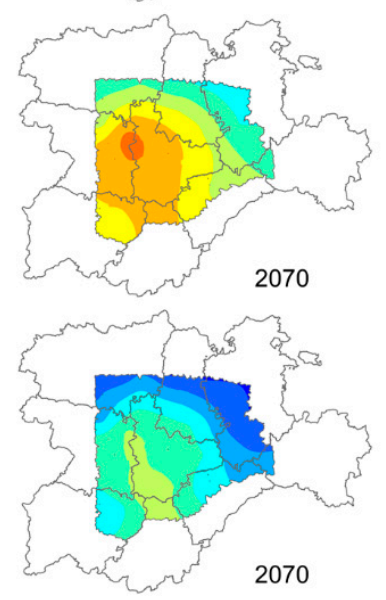

$\mathrm{CO}_{2}\left(\mathrm{t} \mathrm{ha}^{-1}\right)$

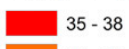

$38-41$

$41-44$

$\square 4-47$
$\square$

$47-50$

$50-53$

$53-56$

$56-59$

$\square$ - $59-62$

Figure 7. Biomass spatial distribution in the area of study for the baseline, 2050 and 2070 scenarios with (a) the usual cultivation period and (b) an extended cultivation period. $\mathrm{CO}_{2}$ sequestration in the area of study for the baseline, 2050 and 2070 scenarios considering (c) current cultivation period and (d) an extended cultivation period.

\section{Conclusions}

The spatial distribution of evapotranspiration in 2050 and 2070 was simulated with AquaCrop at a regional scale for spring-sown sugar beet in the region of Castilla-y-León (Spain), based on data from the MPI-ESM-LR climate model and the RCP4.5 emission scenario from the AR5. A clear annual $\mathrm{ET}_{0}$ increase was observed in all the area of study in 2050 and 2070, with differences vs. the baseline scenario of up to $200 \mathrm{~mm}$, which would result in monthly ETc increases of up to $40 \mathrm{~mm}$ in July. Yield (at current irrigation levels) would decrease by ca. 9\% in both 2050 and 2070 in the central zone of the area of study. This overall yield decrease would be aggravated in the case of decreasing precipitation levels, or increased frequency of extreme events of drought, which seem to be likely in the future. In a similar fashion, the assimilated $\mathrm{CO}_{2}$ would decrease from $49 \mathrm{t} /$ ha in the baseline scenario to 46 and $47 \mathrm{t} / \mathrm{ha}$ in the 2050 and 2070 scenarios, respectively. However, new opportunities for adaptation may arise by lengthening the sugar beet cultivation cycle, delaying the harvest and advancing the sowing. These measures, along with more efficient strategies of irrigation, could result in higher yields (up to $17 \%$ higher) and higher amounts of stored $\mathrm{CO}_{2}$ (9\% and 13\% higher in 2050 and 2070, respectively). Keeping in mind the uncertainty and errors associated to these methodologies, the results coincide with the findings of other studies at different scales and in different regions of Europe: The most suitable cultivation zones for some crops would move northwards to cooler zones, and even higher yields may be obtained by the implementation of appropriate adaptation measures. In this context, in order to have tools available to face potential future adverse situations, efforts aimed at minimizing the uncertainty of the methodologies used for the projection of future scenarios, at evaluating the existing 
strategies of adaptation of the different crops to Climate Change, and at devising new ones are more necessary than ever.

Supplementary Materials: The following are available online at http://www.mdpi.com/2073-4395/10/1/91/s1, Figure S1: Flowchart summarizing the methodology used in the study; Table S1: Comparison between observed and interpolated annual $\mathrm{ET}_{0}$ values for the weather stations for "leave one out" cross-validation.

Author Contributions: Conceptualization, L.F.S.-S., S.H.-N. and J.M.-G.; methodology, N.M.S.A.d.V. and N.M.R.-P.; software, L.F.S.-S.; validation, N.M.S.A.d.V., N.M.R.-P. and S.H.-N.; formal analysis, L.F.S.-S. and P.M.-R.; investigation, L.F.S.-S.; resources, S.H.-N., J.L.M.-R. and J.M.-G.; data curation, N.M.S.A.d.V. and N.M.R.-P.; writing-original draft preparation, L.F.S.-S. and P.M.-R.; writing-review and editing, L.F.S.-S. and P.M.-R.; visualization, L.F.S.-S., N.M.S.A.d.V., N.M.R.-P. and P.M.-R.; supervision, S.H.-N., J.L.M.-R. and J.M.-G.; project administration, S.H.-N. and J.M.-G.; funding acquisition, S.H.-N. and J.L.M.-R. All authors have read and agreed to the published version of the manuscript.

Funding: This research was funded by the European Union LIFE+ Programme, under project “ $\mathrm{CO}_{2}$ Operation: Integrated agroforestry practices and nature conservation against climate change" (ref. LIFE11 ENV/ES/000535). L.F.S.-S. would like to thank the "Ayudas a la Contratación de Personal Investigador de Reciente Titulación (2009-2013)" scholarship program, co-funded by the Education Department of Junta de Castilla y León regional government and the European Social Fund.

Acknowledgments: The authors wish to acknowledge the collaboration of AIMCRA (Asociación de Investigación para la Mejora del Cultivo de la Remolacha Azucarera) and L.F.S.-S. would like to thank Míriam Cimas Valencia, María Jesús Rodríguez-Triana and Luis Pablo Prieto for their support.

Conflicts of Interest: The authors declare no conflict of interest. The funders had no role in the design of the study; in the collection, analyses, or interpretation of data; in the writing of the manuscript, or in the decision to publish the results.

\section{References}

1. De Junta, C.Y.L. Estadísticas Agrarias: Campaña Remolachera 2018/2019. Available online: https: //agriculturaganaderia.jcyl.es/web/jcyl/AgriculturaGanaderia/es/Plantilla100/1284903366867/____ (accessed on 23 November 2019).

2. AIMCRA. Plan 2020 para la sostenibilidad de la remolacha azucarera. In Revista AIMCRA; AIMCRA: Valladolid, Spain, 2015; Volume 120, pp. 29-31.

3. Centeno Malfaz, J.A.; Morillo-Velarde Pérez-Barquero, R. Cómo Realizar un Balance Hídrico; AIMCRA Asociación de Investigación para la Mejora del Cultivo de la Remolacha Azucarera: Valladolid, Spain, 2005; Volume 86, pp. 6-10.

4. Rosenzweig, C.; Strzepek, K.M.; Major, D.C.; Iglesias, A.; Yates, D.N.; McCluskey, A.; Hillel, D. Water resources for agriculture in a changing climate: International case studies. Glob. Environ. Chang. 2004, 14, 345-360. [CrossRef]

5. Iglesias, A.; Garrote, L. Adaptation strategies for agricultural water management under climate change in Europe. Agric. Water Manag. 2015, 155, 113-124. [CrossRef]

6. Rana, G.; Katerji, N. Measurement and estimation of actual evapotranspiration in the field under Mediterranean climate: A review. Eur. J. Agron. 2000, 13, 125-153. [CrossRef]

7. Ding, R.; Kang, S.; Vargas, R.; Zhang, Y.; Hao, X. Multiscale spectral analysis of temporal variability in evapotranspiration over irrigated cropland in an arid region. Agric. Water Manag. 2013, 130, 79-89. [CrossRef]

8. García-Garizábal, I.; Causapé, J.; Abrahao, R.; Merchan, D. Impact of Climate Change on Mediterranean Irrigation Demand: Historical Dynamics of Climate and Future Projections. Water Resour. Manag. 2014, 28, 1449-1462. [CrossRef]

9. Espadafor, M.; Lorite, I.J.; Gavilán, P.; Berengena, J. An analysis of the tendency of reference evapotranspiration estimates and other climate variables during the last 45 years in Southern Spain. Agric. Water Manag. 2011, 98, 1045-1061. [CrossRef]

10. Vicente-Serrano, S.M.; Azorin-Molina, C.; Sanchez-Lorenzo, A.; Revuelto, J.; Morán-Tejeda, E.; López-Moreno, J.I.; Espejo, F. Sensitivity of reference evapotranspiration to changes in meteorological parameters in Spain (1961-2011). Water Resour. Res. 2014, 50, 8458-8480. [CrossRef]

11. Vicente-Serrano, S.M.; Azorin-Molina, C.; Sanchez-Lorenzo, A.; Morán-Tejeda, E.; Lorenzo-Lacruz, J.; Revuelto, J.; López-Moreno, J.I.; Espejo, F. Temporal evolution of surface humidity in Spain: Recent trends and possible physical mechanisms. Clim. Dyn. 2013, 42, 2655-2674. [CrossRef] 
12. Vogel, A. Climate Change 2007: Impacts, adaptation and vulnerability. In Contribution of Working Group II to the Fourth Assessment Report of the IPCC; Cambridge University Press: Cambridge, UK; New York, NY, USA, 2007; Volume 4.

13. van Vuuren, D.P.; Edmonds, J.; Kainuma, M.; Riahi, K.; Thomson, A.; Hibbard, K.; Hurtt, G.C.; Kram, T.; Krey, V.; Lamarque, J.-F.; et al. The representative concentration pathways: An overview. Clim. Chang. 2011, 109, 5-31. [CrossRef]

14. IPCC. Climate Change 2014: Synthesis Report. In Fifth Assessment Report of the Intergovernmental Panel on Climate Change; IPCC: Geneva, Switzerland, 2014; p. 151.

15. Urbano Terron, P. Impactos del Cambio Climático sobre la Producción Vegetal. In Repercusiones del Cambio Climatico en la Agricultura y la Alimentacion Mundial; Lamo de Espinosa, J., Urbano Terron, P., Eds.; AEFAO: Madrid, Spain, 2008; p. 144.

16. Southworth, J.; Randolph, J.C.; Habeck, M.; Doering, O.C.; Pfeifer, R.A.; Rao, D.G.; Johnston, J.J. Consequences of future climate change and changing climate variability on maize yields in the midwestern United States. Agric. Ecosyst. Environ. 2000, 82, 139-158. [CrossRef]

17. Grassini, P.; van Bussel, L.G.J.; Van Wart, J.; Wolf, J.; Claessens, L.; Yang, H.; Boogaard, H.; de Groot, H.; van Ittersum, M.K.; Cassman, K.G. How good is good enough? Data requirements for reliable crop yield simulations and yield-gap analysis. Field Crops Res. 2015, 177, 49-63. [CrossRef]

18. Steduto, P.; Raes, D.; Hsiao, T.; Fereres, E.; Heng, L.; Izzi, G.; Hoogeveen, J. AquaCrop: A new model for crop prediction under water deficit conditions. Options Méditerr. Ser. A 2009, 33, 285-292.

19. Steduto, P.; Hsiao, T.C.; Fereres, E.; Raes, D. Crop Yield Response to Water; FAO: Rome, Italy, 2012; Volume 66, p. 505.

20. UNFCCC Secretariat. Compendium on Methods and Tools to Evaluate Impacts of, and Vulnerability and Adaptation to, Climate Change; UNFCCC: Bonn, Germany, 2008; p. 155.

21. García-Vila, M.; Fereres, E. Combining the simulation crop model AquaCrop with an economic model for the optimization of irrigation management at farm level. Eur. J. Agron. 2012, 36, 21-31. [CrossRef]

22. Malik, A.; Shakir, A.S.; Ajmal, M.; Khan, M.J.; Khan, T.A. Assessment of AquaCrop Model in Simulating Sugar Beet Canopy Cover, Biomass and Root Yield under Different Irrigation and Field Management Practices in Semi-Arid Regions of Pakistan. Water Resour. Manag. 2017, 31, 4275-4292. [CrossRef]

23. Malik, A.; Shakir, A.S.; Khan, M.J.; Ajmal, M.; Khattak, M.S.; Khan, T.A.; Haq, Z.U.; Khan, M.A.; Ijaz, N. Modeling Sugar Beet Response to Different Combinations of On-Farm Water Management Practices Under Semi-arid Sub-tropical Environment. Sugar Tech 2018, 21, 122-134. [CrossRef]

24. Gobin, A.; Kersebaum, K.; Eitzinger, J.; Trnka, M.; Hlavinka, P.; Takáč, J.; Kroes, J.; Ventrella, D.; Marta, A.; Deelstra, J.; et al. Variability in the Water Footprint of Arable Crop Production across European Regions. Water 2017, 9, 93. [CrossRef]

25. Garcia-Vila, M.; Morillo-Velarde, R.; Fereres, E. Modeling Sugar Beet Responses to Irrigation with AquaCrop for Optimizing Water Allocation. Water 2019, 11, 1918. [CrossRef]

26. Zhang, X.; Kang, S.; Zhang, L.; Liu, J. Spatial variation of climatology monthly crop reference evapotranspiration and sensitivity coefficients in Shiyang river basin of northwest China. Agric. Water Manag. 2010, 97, 1506-1516. [CrossRef]

27. Tanasijevic, L.; Todorovic, M.; Pereira, L.S.; Pizzigalli, C.; Lionello, P. Impacts of climate change on olive crop evapotranspiration and irrigation requirements in the Mediterranean region. Agric. Water Manag. 2014, 144, 54-68. [CrossRef]

28. Resop, J.P.; Fleisher, D.H.; Timlin, D.J.; Mutiibwa, D.; Reddy, V.R. Climate, Water Management, and Land Use: Estimating Potential Potato and Corn Production in the U.S. Northeastern Seaboard Region. Trans. ASABE 2016, 59, 1539-1553.

29. Bird, D.N.; Benabdallah, S.; Gouda, N.; Hummel, F.; Koeberl, J.; La Jeunesse, I.; Meyer, S.; Prettenthaler, F.; Soddu, A.; Woess-Gallasch, S. Modelling climate change impacts on and adaptation strategies for agriculture in Sardinia and Tunisia using AquaCrop and value-at-risk. Sci. Total Environ. 2016, 543, 1019-1027. [CrossRef] [PubMed]

30. Khordadi, M.J.; Olesen, J.E.; Alizadeh, A.; Nassiri Mahallati, M.; Ansari, H.; Sanaeinejad, H. Climate Change Impacts and Adaptation for Crop Management of Winter Wheat and Maize in the Semi-Arid Region of Iran. Irrig. Drain. 2019, 68, 841-856. [CrossRef] 
31. Dubey, S.K.; Sharma, D. Assessment of climate change impact on yield of major crops in the Banas River Basin, India. Sci. Total Environ. 2018, 635, 10-19. [CrossRef] [PubMed]

32. Robert, J.H.; Susan, C.; Juan, P.; Peter, J.; Andrew, J.; Karen, R. WorldClim. Available online: https: //www.worldclim.org/ (accessed on 8 January 2020).

33. Hijmans, R.J.; Cameron, S.E.; Parra, J.L.; Jones, P.G.; Jarvis, A. Very high resolution interpolated climate surfaces for global land areas. Int. J. Climatol. 2005, 25, 1965-1978. [CrossRef]

34. Taylor, K.E.; Stouffer, R.J.; Meehl, G.A. An Overview of CMIP5 and the Experiment Design. Bull. Am. Meteorol. Soc. 2012, 93, 485-498. [CrossRef]

35. Dhakal, K.; Kakani, V.G.; Linde, E. Climate Change Impact on Wheat Production in the Southern Great Plains of the US Using Downscaled Climate Data. Atmosphere. Clim. Sci. 2018, 08, 143-162. [CrossRef]

36. Giorgetta, M.A.; Jungclaus, J.; Reick, C.H.; Legutke, S.; Bader, J.; Böttinger, M.; Brovkin, V.; Crueger, T.; Esch, M.; Fieg, K.; et al. Climate and carbon cycle changes from 1850 to 2100 in MPI-ESM simulations for the Coupled Model Intercomparison Project phase 5. J. Adv. Model. Earth Syst. 2013, 5, 572-597. [CrossRef]

37. Wise, M.; Calvin, K.; Thomson, A.; Clarke, L.; Bond-Lamberty, B.; Sands, R.; Smith, S.J.; Janetos, A.; Edmonds, J. Implications of Limiting CO2 Concentrations for Land Use and Energy. Science 2009, 324, 1183-1186. [CrossRef]

38. Thomson, A.M.; Calvin, K.V.; Smith, S.J.; Kyle, G.P.; Volke, A.; Patel, P.; Delgado-Arias, S.; Bond-Lamberty, B.; Wise, M.A.; Clarke, L.E.; et al. RCP4.5: A pathway for stabilization of radiative forcing by 2100. Clim. Chang. 2011, 109, 77-94. [CrossRef]

39. Allen, R.G.; Pereira, L.S.; Raes, D.; Smith, M. Crop Evapotranspiration-Guidelines for Computing Crop Water Requirements_Paper 56; FAO: Rome, Italy, 1998; Volume 300, p. 15.

40. Allen, R.G.; Pruitt, W.O.; Wright, J.L.; Howell, T.A.; Ventura, F.; Snyder, R.; Itenfisu, D.; Steduto, P.; Berengena, J.; Yrisarry, J.B.; et al. A recommendation on standardized surface resistance for hourly calculation of reference ETo by the FAO56 Penman-Monteith method. Agric. Water Manag. 2006, 81, 1-22. [CrossRef]

41. AIMCRA. Recomendaciones de Cultivo: Zona Norte. Available online: http://www.aimcra.es/ Recomendaciones/RecomendacionesNorte.aspx (accessed on 8 January 2020).

42. Raes, D.; Steduto, P.; Hsiao, T.C.; Fereres, E. AquaCropThe FAO Crop Model to Simulate Yield Response to Water: II. Main Algorithms and Software Description. Agron. J. 2009, 101, 438-447. [CrossRef]

43. Stricevic, R.; Cosic, M.; Djurovic, N.; Pejic, B.; Maksimovic, L. Assessment of the FAO AquaCrop model in the simulation of rainfed and supplementally irrigated maize, sugar beet and sunflower. Agric. Water Manag. 2011, 98, 1615-1621. [CrossRef]

44. Sánchez-Sastre, L.F.; Martín-Ramos, P.; Navas-Gracia, L.M.; Hernández-Navarro, S.; Martín-Gil, J. Impact of Climatic Variables on Carbon Content in Sugar Beet Root. Agronomy 2018, 8, 147. [CrossRef]

45. Hoffmann, C.M.; Kluge-Severin, S. Growth analysis of autumn and spring sown sugar beet. Eur. J. Agron. 2011, 34, 1-9. [CrossRef]

46. Malnou, C.S.; Jaggard, K.W.; Sparkes, D.L. A canopy approach to nitrogen fertilizer recommendations for the sugar beet crop. Eur. J. Agron. 2006, 25, 254-263. [CrossRef]

47. Malnou, C.S.; Jaggard, K.W.; Sparkes, D.L. Nitrogen fertilizer and the efficiency of the sugar beet crop in late summer. Eur. J. Agron. 2008, 28, 47-56. [CrossRef]

48. Rinaldi, M.; Vonella, A.V. The response of autumn and spring sown sugar beet (Beta vulgaris L.) to irrigation in Southern Italy: Water and radiation use efficiency. Field Crops Res. 2006, 95, 103-114. [CrossRef]

49. Martínez Quesada, J.J. Surbet. Modelo Fisiológico de Desarrollo de la Remolacha Azucarera de Siembra Otoñal; Universidad de Sevilla: Sevilla, Spain, 2008.

50. Ahmadzadeh Araji, H.; Wayayok, A.; Massah Bavani, A.; Amiri, E.; Abdullah, A.F.; Daneshian, J.; Teh, C.B.S. Impacts of climate change on soybean production under different treatments of field experiments considering the uncertainty of general circulation models. Agric. Water Manag. 2018, 205, 63-71. [CrossRef]

51. Ahmadzadeh Araji, H.; Wayayok, A.; Khayamim, S.; Teh, C.B.S.; Fikri Abdullah, A.; Amiri, E.; Massah Bavani, A. Calibration of the Aquacrop Model to Simulate Sugar Beet Production and Water Productivity under Different Treatments. Appl. Eng. Agric. 2019, 35, 211-219. [CrossRef]

52. Raziei, T.; Pereira, L.S. Spatial variability analysis of reference evapotranspiration in Iran utilizing fine resolution gridded datasets. Agric. Water Manag. 2013, 126, 104-118. [CrossRef]

53. New, M.; Hulme, M.; Jones, P. Representing Twentieth-Century Space-Time Climate Variability. Part I: Development of a 1961-90 Mean Monthly Terrestrial Climatology. J. Clim. 1999, 12, 829-856. [CrossRef] 
54. Ribalaygua, J.; Pino, M.R.; Pórtoles, J.; Roldán, E.; Gaitán, E.; Chinarro, D.; Torres, L. Climate change scenarios for temperature and precipitation in Aragón (Spain). Sci. Total Environ. 2013, 463, 1015-1030. [CrossRef] [PubMed]

55. Heng, L.K.; Hsiao, T.; Evett, S.; Howell, T.; Steduto, P. Validating the FAO AquaCrop Model for Irrigated and Water Deficient Field Maize. Agron. J. 2009, 101, 488-498. [CrossRef]

56. Moreno, J.M.; Álvarez Cobelas, M.; Benito, G.; Catalán, J.; Ramos, M.; Rosa, D.d.l.; Valladares Ros, F.; Zazo, C. Principales Conclusiones de la Evaluación Preliminar de los Impactos en España Por Efecto del Cambio Climático; Oficina Española de Cambio Climático, Ministerio de Medio Ambiente: Madrid, Spain, 2005; p. 35.

57. Manderscheid, R.; Pacholski, A.; Weigel, H.-J. Effect of free air carbon dioxide enrichment combined with two nitrogen levels on growth, yield and yield quality of sugar beet: Evidence for a sink limitation of beet growth under elevated $\mathrm{CO}_{2}$. Eur. J. Agron. 2010, 32, 228-239. [CrossRef]

58. Vanuytrecht, E.; Raes, D.; Willems, P. Regional and global climate projections increase mid-century yield variability and crop productivity in Belgium. Reg. Environ. Chang. 2015, 16, 659-672. [CrossRef]

59. Rashid, M.A.; Jabloun, M.; Andersen, M.N.; Zhang, X.; Olesen, J.E. Climate change is expected to increase yield and water use efficiency of wheat in the North China Plain. Agric. Water Manag. 2019, 222, 193-203. [CrossRef]

60. Ortiz, R.; Sayre, K.D.; Govaerts, B.; Gupta, R.; Subbarao, G.V.; Ban, T.; Hodson, D.; Dixon, J.M.; Iván Ortiz-Monasterio, J.; Reynolds, M. Climate change: Can wheat beat the heat? Agric. Ecosyst. Environ. 2008, 126, 46-58. [CrossRef]

61. Battisti, R.; Sentelhas, P.C.; Boote, K.J. Sensitivity and requirement of improvements of four soybean crop simulation models for climate change studies in Southern Brazil. Int. J. Biometeorol. 2017, 62, 823-832. [CrossRef]

62. Scott, R.K.; Jaggard, K.W. Crop physiology and agronomy. In The Sugar Beet Crop; Springer: Berlin/Heidelberg, Germany, 1993; pp. 179-237.

63. Kenter, C.; Hoffmann, C.M.; Märländer, B. Effects of weather variables on sugar beet yield development (Beta vulgaris L.). Eur. J. Agron. 2006, 24, 62-69. [CrossRef]

64. Van Heemst, H. Plant Data Values Required for Simple Crop Growth Simulation Models: Review and Bibliography; CABO: Wageningen, The Netherlands, 1988; p. 102.

65. Lorite, I.J.; Ramírez-Cuesta, J.M.; Cruz-Blanco, M.; Santos, C. Using weather forecast data for irrigation scheduling under semi-arid conditions. Irrig. Sci. 2015, 33, 411-427. [CrossRef]

66. AIMCRA. Prolongación de Ciclo en Remolacha Azucarera: Aumento de Producción; AIMCRA Asociación de Investigación Para la Mejora del Cultivo de la Remolacha Azucarera: Valladolid, Spain, 2007; Volume 96, pp. 11-12.

67. Hoffmann, C.M.; Kluge-Severin, S. Light absorption and radiation use efficiency of autumn and spring sown sugar beets. Field Crops Res. 2010, 119, 238-244. [CrossRef]

68. Hull, R.; Webb, D.J. The effect of sowing date and harvesting date on the yield of sugar beet. J. Agric. Sci. 1970, 75, 223. [CrossRef]

69. Falloon, P.; Betts, R. Climate impacts on European agriculture and water management in the context of adaptation and mitigation-The importance of an integrated approach. Sci. Total Environ. 2010, 408, 5667-5687. [CrossRef] [PubMed]

70. Osborne, T.; Rose, G.; Wheeler, T. Variation in the global-scale impacts of climate change on crop productivity due to climate model uncertainty and adaptation. Agric. For. Meteorol. 2013, 170, 183-194. [CrossRef]

71. García-López, J.; Lorite, I.J.; García-Ruiz, R.; Domínguez, J. Evaluation of three simulation approaches for assessing yield of rainfed sunflower in a Mediterranean environment for climate change impact modelling. Clim. Chang. 2014, 124, 147-162. [CrossRef]

72. Saarikko, R.A. Applying a site based crop model to estimate regional yields under current and changed climates. Ecol. Model. 2000, 131, 191-206. [CrossRef]

(C) 2020 by the authors. Licensee MDPI, Basel, Switzerland. This article is an open access article distributed under the terms and conditions of the Creative Commons Attribution (CC BY) license (http://creativecommons.org/licenses/by/4.0/). 